\title{
Negin Miri. The Survival and Demise of Pre-Islamic Traditions and Zoroastrianism in Islamic Iran: Case Study of Fars based on the 10th- 14th Century A.D. Literary Sources
}

\section{Rémy Boucharlat}

\section{(2) OpenEdition}

\section{Journals}

Édition électronique

URL : http://journals.openedition.org/abstractairanica/40556

DOI : 10.4000/abstractairanica.40556

ISSN : 1961-960X

Éditeur :

CNRS (UMR 7528 Mondes iraniens et indiens), Éditions de l'IFRI

Édition imprimée

Date de publication : 1 décembre 2013

ISSN : 0240-8910

\section{Référence électronique}

Rémy Boucharlat, « Negin Miri. The Survival and Demise of Pre-Islamic Traditions and Zoroastrianism in Islamic Iran: Case Study of Fars based on the 10th- 14th Century A.D. Literary Sources », Abstracta Iranica [En ligne], Volume 32-33 | 2013, document 188, mis en ligne le 01 juillet 2016, consulté le 26 septembre 2020. URL : http://journals.openedition.org/abstractairanica/40556 ; DOI : https://doi.org/ 10.4000/abstractairanica.40556

Ce document a été généré automatiquement le 26 septembre 2020.

Tous droits réservés 


\title{
Negin Miri. The Survival and Demise of Pre-Islamic Traditions and Zoroastrianism in Islamic Iran: Case Study of Fars based on the 10th- 14th Century A.D. Literary Sources
}

\author{
Rémy Boucharlat
}

\section{RÉFÉRENCE}

Negin Miri. «The Survival and Demise of Pre-Islamic Traditions and Zoroastrianism in Islamic Iran: Case Study of Fars based on the 10th- 14th Century A.D. Literary Sources ». Nāme-ye Irān-e Bāstān, 8/1-2, 2008-9, p. 25-41.

La vitalité du zoroastrisme dans le Fārs à l'époque sassanide est bien connue, peut-être surestimée du fait de la position de cette province au cœur de l'empire sassanide naissant. La survivance de cette religion après l'arrivée de l'Islam est également bien attestée pendant plusieurs siècles, ses adeptes pouvant occuper des fonctions importantes. C'est au tournant des $\mathrm{X}^{\mathrm{e}}$ et $\mathrm{XI}^{\mathrm{e}}$ siècles que la situation change nettement, due entre autres selon l'A. à l'activité de ŠeyH Abū Eshāa, musulman actif, fils de zoroastriens convertis. Le silence des textes musulmans et l'absence de textes zoroastriens après cette date portent témoignage de ces changements, plus que les données archéologiques incertaines que l'A. convoque au début de son article. 


\section{AUTEURS}

RÉMY BOUCHARLAT

CNRS, Lyon 